University of Nebraska - Lincoln

DigitalCommons@University of Nebraska - Lincoln

\title{
Selecting and conserving lands for biodiversity: The role of remote sensing
}

John Wiens

The Nature Conservancy

Robert Sutter

The Nature Conservancy

Mark Anderson

The Nature Conservancy

Jon Blanchard

The Nature Conservancy

Analie Barnett

The Nature Conservancy

See next page for additional authors

Follow this and additional works at: https://digitalcommons.unl.edu/usafresearch

Part of the Aerospace Engineering Commons

Wiens, John; Sutter, Robert; Anderson, Mark; Blanchard, Jon; Barnett, Analie; Aguilar-Amuchastegui, Naikoa; Avery, Chadwick; and Laine, Stephen, "Selecting and conserving lands for biodiversity: The role of remote sensing" (2009). U.S. Air Force Research. 31.

https://digitalcommons.unl.edu/usafresearch/31

This Article is brought to you for free and open access by the U.S. Department of Defense at DigitalCommons@University of Nebraska - Lincoln. It has been accepted for inclusion in U.S. Air Force Research by an authorized administrator of DigitalCommons@University of Nebraska - Lincoln. 


\section{Authors}

John Wiens, Robert Sutter, Mark Anderson, Jon Blanchard, Analie Barnett, Naikoa Aguilar-Amuchastegui, Chadwick Avery, and Stephen Laine 


\title{
Selecting and conserving lands for biodiversity: The role of remote sensing
}

\author{
John Wiens ${ }^{\mathrm{a}, *}$, Robert Sutter ${ }^{\mathrm{b}}$, Mark Anderson ${ }^{\mathrm{c}}$, Jon Blanchard ${ }^{\mathrm{b}}$, Analie Barnett ${ }^{\mathrm{b}}$, \\ Naikoa Aguilar-Amuchastegui ${ }^{b}$, Chadwick Avery ${ }^{\mathrm{d}}$, Stephen Laine ${ }^{\mathrm{d}}$ \\ a The Nature Conservancy, 4245 North Fairfax Drive, Suite 100, Arlington, VA 22203, USA \\ ${ }^{b}$ The Nature Conservancy, 6114 Fayetteville Road, Durham, NC 27713, USA \\ c The Nature Conservancy, 11 Avenue de Lafayette, Boston, MA 02111, USA \\ d Eglin Air Force Base, Natural Resource Branch, 107 N. Highway 85, Niceville, FL 32578, USA
}

\section{A R T I C L E I N F O}

Article history:

Received 10 December 2007

Received in revised form 5 May 2008

Accepted 1 June 2008

\section{Keywords:}

Remote sensing

Forest management

Ecological monitoring

Conservation

Connecticut River

Eglin Air Force Base

\begin{abstract}
A B S T R A C T
A major focus of conservation is on protecting areas to ensure the persistence of biological diversity. Because such areas may be large, not easily accessible, subject to change, and sensitive to the surrounding landscape, remote sensing can be a valuable tool in establishing and managing protected areas. We describe three case studies to illustrate how remote sensing can contribute to setting priorities for conservation actions, monitoring the status of conservation targets, and evaluating the effectiveness of conservation strategies. In the Connecticut River watershed, remote sensing has been used to assess flood regimes and identify key areas of floodplain forests and their context for conservation planning. At Eglin Air Force Base in Florida, remote sensing has provided information to assess the effectiveness of management strategies to restore fire to the longleaf pine sandhills ecosystem, control invasive species, and prioritize annual prescribed burns. In eastern US forests, remote sensing is being used to evaluate the ecological condition and changes at properties where direct access would be difficult.

As the resolution and capacities of remote-sensing technology continue to develop, however, several issues are becoming increasingly important. It is essential that the spatial and temporal resolution of remotesensing data be matched to the relevant scales of biodiversity, major threats, and management actions. Data layers must be compatible, both in scale and in measurement properties, and key patterns must be distinguished from irrelevant detail, especially at the finer scales of application in local management. Combining remote sensing with ground surveys can expand the array of information used in management and contribute to the ecological interpretation of remote-sensing data. Because conservation funds are always limited, remote sensing also must be cost effective. This requires balancing the wealth of detail afforded by ever-finer resolution of remote-sensing data with what is actually needed to implement sound conservation and management. Remote sensing is a valuable tool, but it is not a panacea for all of the challenges of conservation monitoring and management.
\end{abstract}

Published by Elsevier Inc.

\section{Introduction}

Protected areas have long been the cornerstones of conservation. By providing places in which populations and species can persist and communities and ecosystems can carry out ecological functions, such areas help to preserve the Earth's biodiversity in the face of burgeoning human populations, intensified land use, and fragmentation of landscapes.

Initially, most protected areas were set aside because of their spectacular natural beauty, the occurrence of populations of rare or endangered species, or their value in harboring species of recreational interest. More recently, the identification and prioritization of places

\footnotetext{
* Corresponding author. Present address: PRBO Conservation Science, 3820 Cypress Dr. \#11, Petaluma, CA 94954, USA. Tel.: +1 707781 2555x319; fax: +1 7077651685. E-mail address: jwiens@prbo.org (J. Wiens).
}

meriting protection has become more systematic and scientific. Several organizations (e.g., Conservation International, the World Wildlife Fund) have targeted places for global protection based upon the biodiversity they contain-so-called "hotspots" of species richness (Olson \& Dinerstein, 1998; Myers et al., 2000; see http://www. biodiversityhotspots.org/Pages/default.aspx, http://www.worldwildlife.org/science/ecoregions/g200.cfm). Others, such as The Nature Conservancy (TNC), have used inventories of species and communities and assessments of major threats such as development or habitat fragmentation to target areas for protection within broadly defined ecoregions (Groves, 2003). Collectively, such areas are intended to represent the biodiversity of the entire ecoregion, including "coldspots" as well as hotspots of biodiversity (Kareiva \& Marvier, 2003). Systematic conservation planning has become a major focus of conservation and management.

Protected areas, however, cannot be left alone. In the majority of cases, there is a need to restore areas from past land uses, such as 
agriculture or inappropriate forestry. Protected areas may need to be managed to restore the natural ecological processes that are essential to their constituent species and communities. These areas also need to be regularly assessed for changes in condition from natural (succession, natural fire) and less than natural (pests and pathogens, inappropriate fire, recreation, acid deposition) sources.

It has also become apparent that protected areas by themselves will be insufficient to preserve the Earth's biodiversity. Too many protected areas are too small, too many are "protected" in name only, and too many are located in the places no one wants rather than the places that have real conservation value (Scott et al., 2001). To be effective, conservation must expand its vision to encompass the broader landscapes in which protected areas are embedded, for several reasons. First, the status of biodiversity within protected areas may be affected by opportunities and threats in the surrounding landscape; administrative boundaries do not create an impermeable wall around a protected area (Janzen, 1983; Wiens, 2007). Second, these landscapes-the places where people live and work-often have conservation value in their own right, even though they are not "protected" (e.g. UNESCO Biosphere Reserves; see http://www. unesco.org/mab/). They can make important contributions to conservation. Third, the condition of ecological processes such as fire or flooding that occur within (and beyond) a protected area must be considered, for these are what foster the long-term sustainability of biodiversity. Finally, simply protecting an area by some legal means does not ensure that henceforth all will be fine. Conditions change. The effectiveness of the actions taken to protect biodiversity must be monitored and evaluated over time.

Remote sensing plays an important role in assessing the condition of protected areas and facilitating this broadening of focus from protected areas to entire landscapes. For example, resource managers and conservation practitioners are making extensive use of land-cover and land-use information to portray and analyze the landscape context of conservation areas at multiple scales (Wiens et al., in press). Data gathered by remote sensing for the same areas over time are being used to assess changes in landscapes and associated factors, again at multiple scales. The Land Cover Trends Project of the U.S. Geological Survey, for example, has used Landsat imagery from 1973 to 2000 to chart large-scale changes in major land-cover types in the United States (e.g. Loveland et al., 2002). At global or regional scales, remote sensing has provided the foundation for setting spatial priorities about where to focus conservation efforts (e.g. Groves, 2003; Hoekstra et al., 2005). The Normalized Difference Vegetation Index (NDVI; see http://earthobservatory.nasa.gov/Library/MeasuringVegetation/) is widely used to assess regional primary production and the condition and distribution of different vegetation types.

Our focus here is on how information derived from remote sensing can be used to establish spatial priorities for conservation, gauge the status and condition of conservation targets, and evaluate the effectiveness of particular conservation strategies. All of these may involve the use of remote sensing in monitoring. Indeed, in some situations remote sensing is the only way to monitor conservation conditions and effectiveness in landscapes where key areas may be in private ownership and unavailable to direct, on-the-ground monitoring.

To make things tangible, we develop three case studies, using work carried out by TNC. Each of these case studies is a work in progress; we use them to illustrate how remote sensing is being used rather than emphasizing the results it generates. We describe the setting, problem addressed, methods, and outcomes separately for each of these case studies. We conclude by commenting on several realities that may affect the use of remote sensing in conservation: the resolution of the remote sensing data; the value of ground sampling; matching the scale of the data to the conservation objectives; and balancing the costs against the benefits of remote sensing-essentially, "how good is good enough?".

\section{Case study 1: Verifying flooding and setting priorities for floodplain conservation in the Connecticut River watershed}

Floodplains provide critical habitat for a variety of plants and animals. In spring, flood waters replenish the soil, nourishing streamside ecosystems and creating feeding and nursery grounds for fish, but by late summer the soils have dried out. The fluctuating nature of the system has consequences for the associated biota, which is often lush and diverse (Thompson \& Sorenson, 2000). Globally, temperate rivers and their floodplain wetlands are among the most threatened ecosystems (Dynesius \& Nilsson, 1994). In the Northeastern United States, mature and diverse floodplain forests are among the most diminished ecosystems due to clearing for agriculture and development (Anderson et al., 2006).

The Connecticut River mainstem is $660 \mathrm{~km}$ long and drains nearly 3 million ha of northern New England. Floodplain forests are comprised of silver maple (Acer saccharinum), cottonwood (Populus deltoids), black willow (Salix nigra), American elm (Ulmus americana) and green ash (Fraxinus pennsylvanica), with a tangled understory of vines and disturbance-tolerant shrubs. Ferns, sedges, grasses and a surprising array of late-summer flowering plants contribute to the diverse herbaceous layer.

The river mainstem is fragmented by over 2600 dams, including 65 major dams built for hydropower or flood control. Although the river ranks as one of the top three fragmented rivers in North America (Dynesius \& Nilsson, 1994), it nevertheless contains several relatively free-flowing tributaries and the quality of the upper headwaters is very high. The once-extensive floodplain forests along the mainstem and its tributaries have been reduced to isolated fragments by agricultural clearing, road building and hydrologic alteration.

Ecologists have located, mapped and evaluated over 80 remaining stands of floodplain forest in the Connecticut River watershed, more than in any other watershed in the Northeastern United States. Because the river and its dynamics bind the floodplain together, however, conservation cannot be focused on individual places to the exclusion of others but must consider the entire watershed. A unifying floodplain assessment is needed to give context to the patches of remnant floodplain forests, to identify suitable restoration areas, to highlight broad-scale patterns, and to suggest strategies for conserving the floodplain resources. This is where remote sensing comes in.

\subsection{The modeling approach}

The study used data from a variety of scales. We used modeling techniques in a high-resolution (30-m) GIS to map the active floodplain zone and identify patches of undeveloped floodplain communities. Remotely sensed imagery was used to detect areas that currently experience spring flooding. Classification and regression tree analysis (CART; Steinberg \& Colla, 1997) was used in combination with ground inventory to identify the attributes that separated known floodplain forests from other riparian communities. The CART results were applied to the watershed to identify areas most likely to support remaining or restorable floodplain forests (referred to as floodplain forest occurrences). We evaluated the characteristics of each occurrence with respect to its: 1) sustaining processes, based on remotely sensed flooding; 2) landscape context, based on the proportion of land-cover classes and an estimation of dam storage to annual runoff in the appropriate sub-watershed; and 3) habitat quality, based on the size, percent inundation, and natural cover of the occurrence. Lastly, we prioritized the occurrences for conservation action.

Initially we developed a GIS model of the active floodplain that explicitly accounted for fluvial processes, dominated by over-bank flow from the river channel, and hillslope processes, dominated by overland and subsurface flows moving toward the floodplain from upslope (Fels \& Matson, 1997; Strager et al., 2000; full methodology 
described in Anderson et al. in preparation). The result of the model was the identification of a set of spatially distinct potential floodplain forest occurrences separated by natural discontinuities or anthropogenic barriers such as urban or residential development. Most of these modeled occurrences fell within an area that corresponded closely to the FEMA 100-year flood zones and were roughly equivalent to the size and shape of known floodplain-forest occurrences. Overall, some 17,000 individual occurrences were identified, averaging 8 ha in extent and ranging from 0.81 ha to 521 ha. Following Olivero (2003), each occurrence was given a unique identifier and a value indicating the type and size of the adjacent water body. Agricultural land-cover classes were retained as floodplain occurrences, as these were considered to be potentially restorable.

\subsection{Verifying current flooding using remotely sensed imagery}

We determined the extent to which the floodplain occurrences currently experience seasonal flooding by overlaying remotely sensed imagery (30-m resolution Landsat Thematic Mapper-ETM+) from 14 April 2001 (a spring flooding event) and 30 September 2001 (an autumn dry period) for the entire watershed. This set of matched imagery expressed a typical, 1-2-yr, high spring flow and low September flow, based on monthly mean discharge data from the Hamden County, MA, gauging station from 1904 to 2007 (a flow of this magnitude happened 69 out of the 103 years $=67 \%$ ).

To distinguish flooded and non-flooded areas, we developed an additive index using bands 4 (near infrared) and 7 (mid-infrared) (Wang, 2004; Wang et al., 2002). Inundation changes between April and September were quantified by generating a composite image combining three bands. Bands 1 and 2 were derived from the addition of the ETM + bands 4 and 7 for April and September, respectively. The third band, derived from a 30-m slope map (USGS-NED, 2006), allowed us to separate flooded flats from spectrally similar shaded slopes (Fig. 1). All image analysis took place in the ERDAS Imagine 9.0 software environment (Leica Geosystems, Heerbrugg, Switzerland).

We performed an unsupervised classification on the composite image for the entire watershed to create an image containing 15 statistically separable classes. The 15 classes were collapsed into a simple binary image representing flooded and non-flooded pixels. We removed from the data set any discrete areas that were not within $100 \mathrm{~m}$ of a riparian model occurrence, a known floodplain occurrence, or a water feature. We also removed areas that fell on a sloped landform (Fig. 2).

We tested the accuracy of the image classification using a 1-m resolution digital orthophoto tile for 26 April 2001, a day that, according to the gauging station in Hampden County, MA, had a peak discharge similar to that of 14 April. We randomly extracted 150 reference flooded points and an equal number of non-flooded points from the orthophoto. Overlaying these on the flood map, we found the flooded and non-flooded pixel class accuracy to be over 96\%. Our methodology had also correctly identified flooded riparian forests, confirming that the ETM+ optical sensors could penetrate a moderately dense tree canopy. On the strength of the methodology and visual confirmation of test areas, we extrapolated the data to the entire watershed.

\subsection{Watershed-wide projections}

The total area of spring flooding in the watershed amounted to 19,812 ha distributed across streams of various sizes. Of this, $45 \%$ occurred directly on the floodplain occurrences. The remaining area (55\%) largely coincided with wetland and open-water features, a

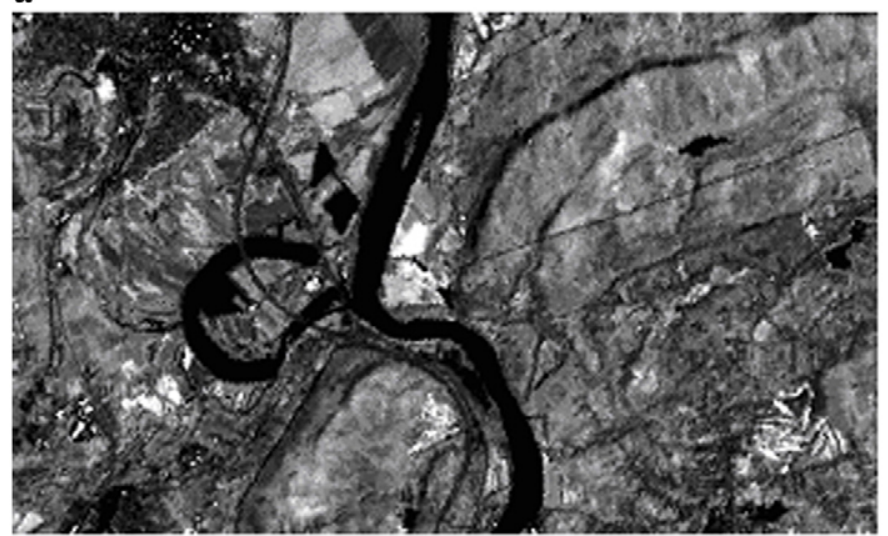

c

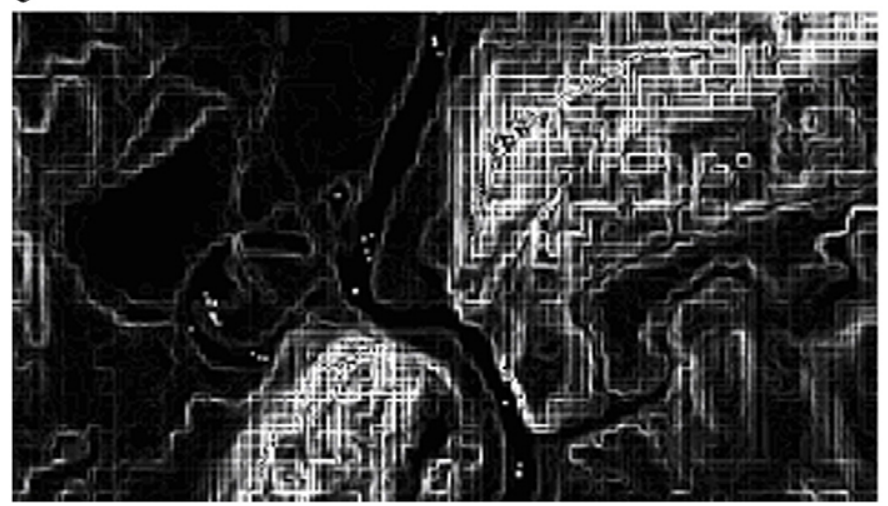

b

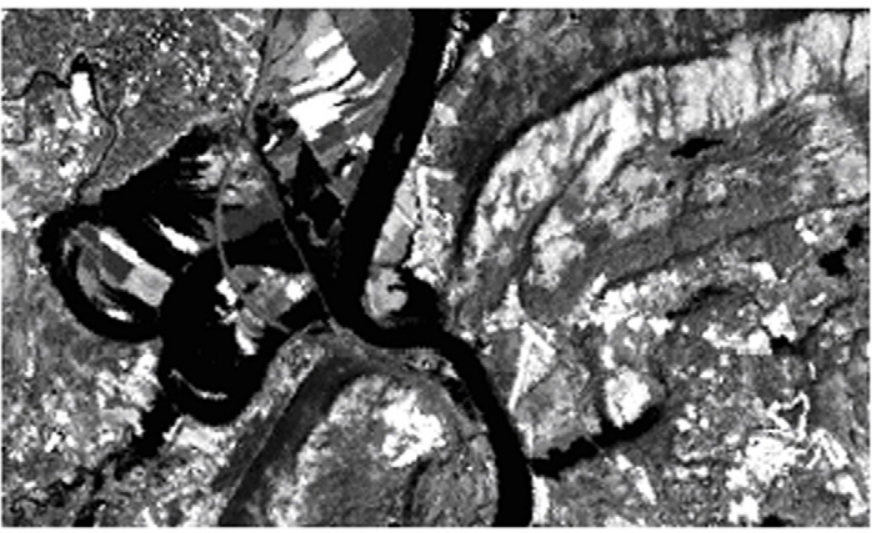

d

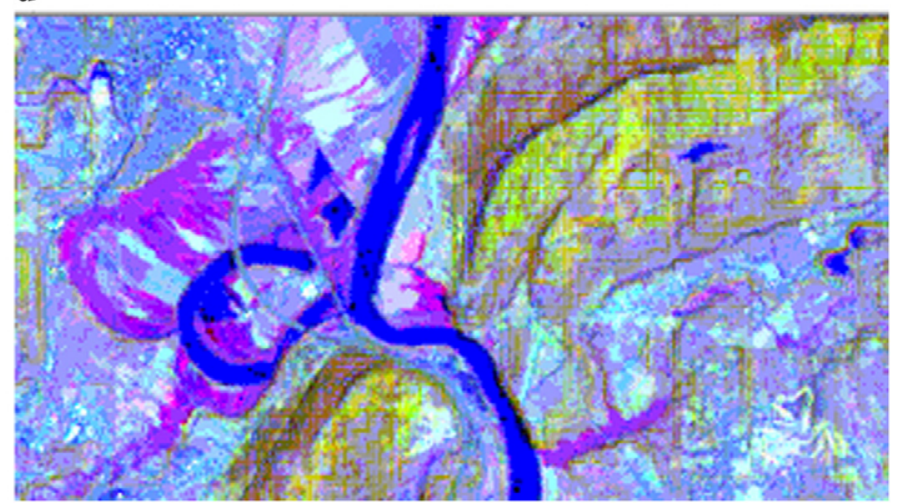

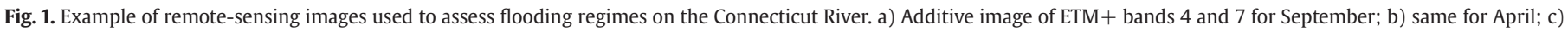

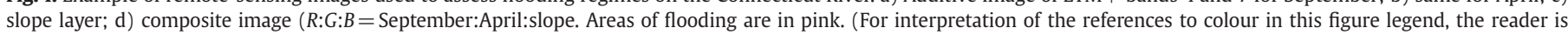
referred to the web version of this article.) 
a

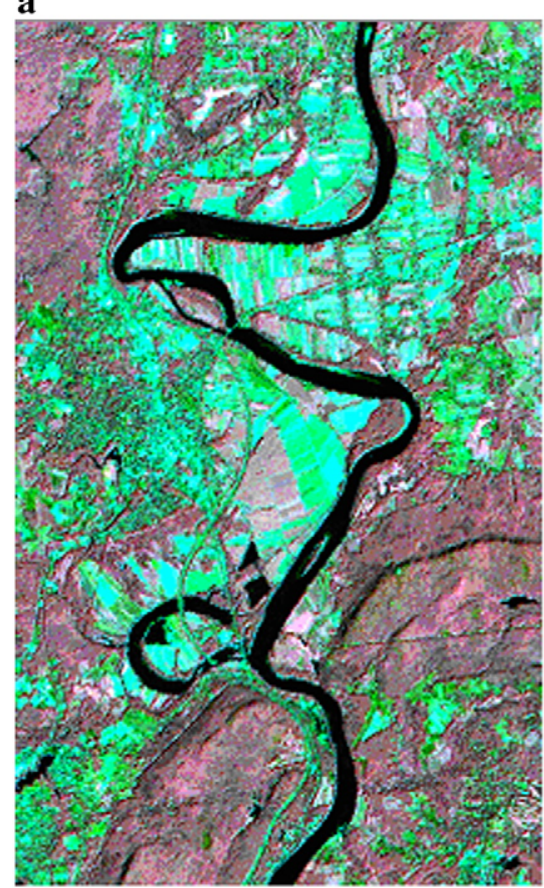

c

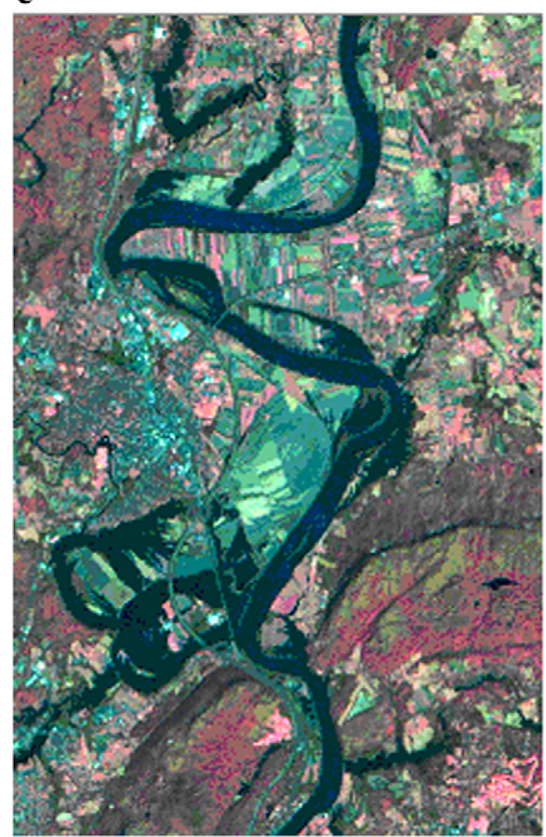

b

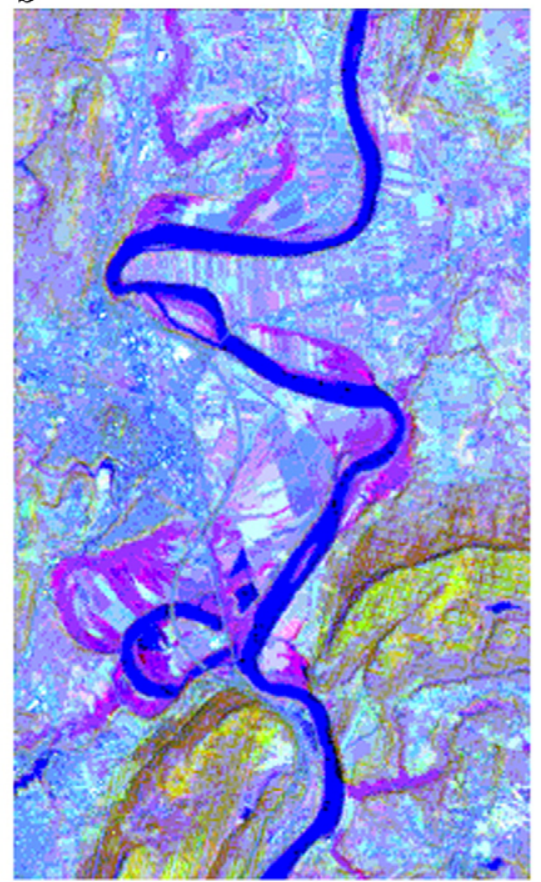

d

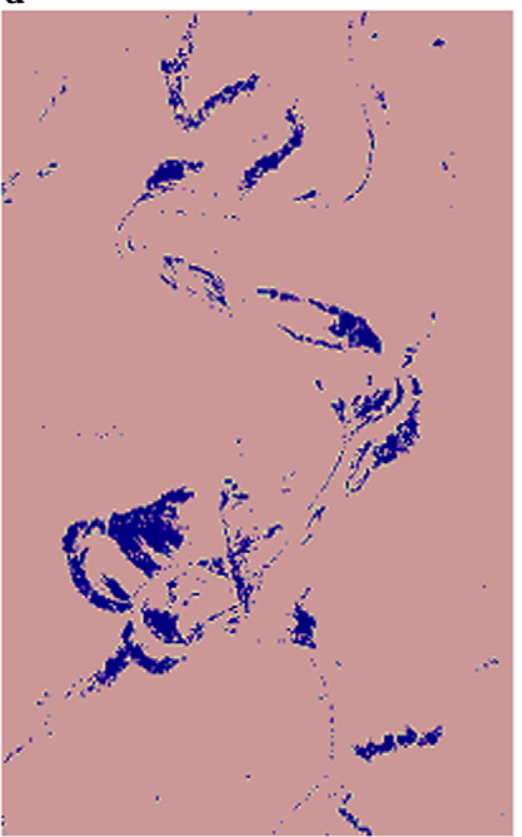

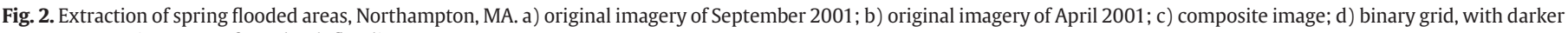
areas representing areas of overbank flooding.

suggesting that these features also expand in spring and contract seasonally.

We used a CART analysis to separate 82 known floodplain forest occurrences from 197 other mapped riparian communities using only attributes available for every occurrence in the watershed. Floodplain forest occurrences could be consistently distinguished from occurrences of other riparian communities using the adjacent stream size, the degree of flooding (percent overlap of the verified flooding on the modeled occurrence), and the elevation mean and minimum. Applying the CART results to the entire set of floodplain occurrences identified a subset of 3272 (19\%) that were the most likely to support floodplain forests.
Based on 73 ground-inventoried floodplain forests that had been ranked for quality, the highest quality (A-ranked) floodplain forests were larger in size, had more active flooding, and had a higher percentage of natural cover than lower-ranked forests (Table 1). A regression analysis indicated that this trend was weak but consistent across all ranked classes $\left(R^{2}=0.21, P=0.0002\right)$. Using these relationships, we evaluated and ranked the predicted floodplain occurrences throughout the watershed based on their size, percent natural cover, percent verified flooding, the hydrologic intactness of adjacent stream reaches, and an index of the landscape/watershed context. The latter was a composite index reflecting the amount of agriculture, residential development, and urban/commercial development found 
Table 1

Average values for Natural Heritage ground inventoried floodplain forest examples.

\begin{tabular}{llllll}
\hline & \multicolumn{2}{l}{ Rank } & & Average/Total \\
\cline { 2 - 4 } & $\mathrm{A}$ & $\mathrm{B}$ & $\mathrm{C}$ & $\mathrm{D}$ & \\
\hline Size (ha) & 98 & 57 & 33 & 3 & 56 \\
Percent verified flooding & $42 \%$ & $33 \%$ & $16 \%$ & $11 \%$ & $29 \%$ \\
Percent natural cover & $73 \%$ & $79 \%$ & $58 \%$ & $53 \%$ & $70 \%$ \\
Count & 14 & 33 & 25 & 1 & 73 \\
\hline
\end{tabular}

The $\mathrm{A}$ (best) to $\mathrm{D}$ (worst) ranking scheme reflects a qualitative assessment done by a Natural Heritage ecologist during a field visit, based on a variety of observable characteristics.

in an 1140-m buffer area immediately surrounding the occurrence, combined with a measure of the hydrologic alteration in the watershed.

Where we had independent site verification, the ground survey strongly corroborated the results of our ranking. For instance, the Elmer Brook occurrence in our top-ranked set was a 40-ha small-river floodplain forest with $99 \%$ natural cover, $47 \%$ verified flooding and only a few minor dams relative to a large annual runoff. It was ranked high for quality (A rank) by the field survey and has been identified through a separate, expert driven, process as a critical site for floodplain forest conservation.

\subsection{Implications}

Previous inventory in the Connecticut River watershed has been limited to locating and evaluating remaining remnants of floodplain forests (Kearsley, 1999; Nichols et al., 2000; Sorenson et al., 1998). By using remote-sensing information to model flood dynamics, we have been able to expand on these inventories to consider areas where sustaining hydrologic processes were still intact and the surrounding landscape and watershed context was suitable for restoring an entire floodplain ecosystem with all its facets and dynamics. Hydrologic processes were accounted for directly through the verification of current flooding using remotely sensed imagery. This analysis, coupled with the imagery, provided compelling evidence to conservationists and managers that the identified areas have restoration potential.

The top sites are now being investigated for land purchasing options and a few are being field-monitored for silver maple seedling establishment. Although we did not directly address the feasibility of floodplain restoration at each site, the verification by remote sensing of current flooding offers an indirect measure for the challenges of restoring a natural flood regime (Henry \& Amoros, 1995) and the landscape/watershed context index gives an indication of obstacles to restoration in the surrounding area.

The challenge in this study was to synthesize information from different scales, technologies, and extents into an ecologically meaningful analysis. The sources of error did not often overlap. For example, the remote imagery appeared to underestimate flooding in some far north areas that retained remnant spring ice, while variability in the ranking of ground-sampled floodplain forest points suggested observer bias of different state ecologists. However, these issues did not prevent broad and consistent trends from being identified. The verified spring flooding data layer, developed through remote sensing, proved essential in separating potential floodplain forests from other riparian communities, in predicting floodplain forest quality and ultimately in ranking areas for potential floodplain restoration. Overall, the work provided a more complete understanding of floodplain dynamics in this watershed, clarifying where conservation action is most likely to succeed.

\section{Case study 2: Evaluating the condition of longleaf pine forests on Eglin Air Force Base, Florida}

Eglin Air Force Base (AFB) is located in the panhandle of Florida, $72 \mathrm{~km}$ east of Pensacola. The 187,780-ha installation is the largest forested military reservation in the United States (U.S. Department of the Air Force, 1998). The primary mission of the base is the testing and evaluation of defense weapon systems; $13 \%$ of the land area is comprised of test and administrative areas, while the majority of the remaining area is forested.

The base encompasses a remarkably diverse ecological area. Upland areas are dominated by longleaf pine (Pinus palustris), including the largest acreage of old growth and the largest public ownership of longleaf pine sandhill forests in the United States (Hiers et al., 2003a). The aquatic systems harbor numerous rare and endemic species and the forested habitat supports the fourth largest population of the federally endangered red-cockaded woodpecker (Picoides borealis) (U.S. Fish and Wildlife Service, 2003). Overall, there are 11 federally-listed and 118 imperiled species, including many with their only known viable populations on the base (Florida Natural Areas Inventory, 1999). Perhaps most significantly, the ecological communities at Eglin AFB occur in a relatively intact landscape, with a mosaic of xeric sandhills grading into mesic terrestrial communities and aquatic systems. Frequent low-intensity fire, the dominant ecological process in longleaf pine communities, has been reintroduced across the base using prescribed burns to maintain and restore ecological communities (Hiers et al., 2003a).

An essential objective of Eglin's adaptive management program is to assess the status and condition of the fire-dependent and actively restored longleaf pine sandhills, which comprise approximately $78 \%$ of the base (Sutter et al., 2001). The spatial extent of the longleaf pine sandhills, combined with decades of fire suppression, widespread invasion of sand pine (Pinus clausa), and limited management resources, necessitated the development of a landscape-scale modeling approach using remotely sensed data.

\subsection{Modeling approach}

To assess the structural and compositional condition of Eglin's longleaf pine sandhills at the landscape scale, a spatially explicit expert model was developed by combining current science on longleaf pine systems with the experience of natural resource managers and translating this knowledge into a GIS modeling framework. The model is currently run using ArcGIS 9.2 Spatial Analyst Extension and Model Builder (ESRI, Redlands, California) with model inputs largely derived from satellite imagery. The model results are aggregated to 1-ha hexagonal monitoring units that are used in conjunction with field data from 201 permanent 1-ha monitoring plots to inform long-term management priorities and to examine the impact of management activities on conservation targets.

\subsection{Model development}

The development of the ecological condition model was an outgrowth of a process to establish desired future conditions (DFCs) for targeted species and ecological systems at Eglin during 2000. DFCs are spatially explicit and time-delimited ecological goals established to guide conservation, land management, and restoration efforts

Table 2

Tier ranking approach selected to establish desired future conditions (DFCs) for the longleaf pine sandhills matrix on Eglin AFB, Florida.

\begin{tabular}{ll}
\hline DFCs tier rank & Qualitative description \\
\hline I & $\begin{array}{l}\text { High quality sites with old growth trees, open understory structure, } \\
\text { diverse native groundcover }\end{array}$ \\
II & $\begin{array}{l}\text { Good quality sites with a longleaf canopy and minimal non-native } \\
\text { groundcover species }\end{array}$ \\
III & $\begin{array}{l}\text { Low quality sites with canopy dominated by off-site species or young } \\
\text { longleaf pine with a dense understory and low diversity and cover of } \\
\text { native groundcover }\end{array}$ \\
\hline
\end{tabular}


(Sutter et al., 2001). Twenty-seven experts from organizations and agencies, including TNC, Eglin AFB, U.S. Fish and Wildlife Service (USFWS), Florida Natural Areas Inventory (FNAI), and the Joseph W. Jones Ecological Research Center, participated in several workshops in 2000 to develop DFCs for Eglin's longleaf pine sandhills matrix. The experts established a ranking system with three tiers (Table 2) that was based on a previous classification of Eglin's longleaf communities by FNAI (Kindell et al., 1997). The workshop participants estimated the proportion of longleaf sandhills within each Tier and prescribed potential management options to improve Tier 2 and Tier 3 sites and maintain Tier 1 areas.

Following the DFCs workshops, the longleaf experts identified eight spatially explicit criteria to define high-quality longleaf pine sandhills at the landscape scale. A subset of the experts used an iterative process to parameterize the GIS model and establish biologically meaningful thresholds for the eight criteria (Hiers et al., 2003b). In the parameterization process, the experts increased the number of condition tiers to four, with Tier 1 representing the highest quality longleaf pine habitat and Tier 4 reflecting the most degraded areas. Fire, as a key process in this ecosystem and an important criterion in the model, received one of the highest weights in the model (Table 3 ).

The condition model inputs are all 30-m integer raster grids translated to a common numeric scale ranging from 1 to 9 . Each $30-\mathrm{m}$ pixel that corresponds to sandhills soils (Lakeland series) is assigned a score for each of the eight criteria. The overall ecological condition of each pixel is derived by combining the eight criteria using a weighted overlay process that multiplies the value of each input by the weight factor (\% influence), and then sums the eight weighted inputs. Pixel scores are grouped into tier classes as follows: Tier 1 (scores $>5.3$ ); Tier 2 ( 4.5 to 5.3 ); Tier 3 ( 2.5 to 4.5 ); and Tier 4 ( 0 to 2.5 ). The tier scores are then aggregated to 1-ha hexagons using an area-weighted average. The model is run on an annual basis.

\subsection{Derivation of model inputs from satellite imagery}

All the land-cover criteria in the Eglin condition model (e.g. sand pine cover, longleaf cover) are derived from satellite imagery. The remaining model inputs (e.g. patch size, road density) are based on fire-management and road GIS data layers. The land-cover inputs were initially created from a 1998 baseline land-cover classification with 17 classes. Inputs are updated annually using current-date satellite imagery and a multiple-date change detection technique.

The initial classification was generated using 30-m Landsat 4 Thematic Mapper (TM) imagery and a procedure based on NOAA's Coastal Change Analysis Program (C-CAP; Dobson et al., 1995). The C-CAP classification consists of three Level I superclasses (upland, wetland, and

Table 3

Criteria used to assess the ecological condition of longleaf pine sandhill communities on Eglin AFB and their overall influence in the GIS condition model.

\begin{tabular}{lll}
\hline Criteria & $\begin{array}{l}\text { Annually } \\
\text { updated }\end{array}$ & $\begin{array}{l}\text { Overall model } \\
\text { influence (\%) }\end{array}$ \\
\hline Canopy density & Yes & 10 \\
Deciduous cover & Yes & 10 \\
Fire sub-model inputs & Yes & 18 \\
$\quad$ Time since last burn (years) (50\%) & & \\
$\quad$ Fire frequency since 1972 (total \# of burns) (50\%) & & 26 \\
Longleaf pine cover & Yes & 6 \\
Patch Size (road-bounded polygon) & No & 14 \\
Red cockaded woodpecker (RCW) sub-model inputs & Yes \\
$\quad$ & & \\
Optimal RCW habitat (50\%) & & \\
$\quad$ Inactive RCW trees (25\%) & & \\
$\quad$ Presence/absence of longleaf old-growth (25\%) & No & 4 \\
Road density & Yes \\
Sand pine cover & 12
\end{tabular}

water/submerged land). Each of these superclasses is subdivided into classes and subclasses at Levels II and III, respectively. This procedure was further modified to distinguish between longleaf and sand pine. In Eglin's baseline land-cover classification, all imagery was first registered to the Eglin base map using a cubic convolution method. A k-means clustering algorithm was then used to classify on TM bands 1, 2, 3, 4, 5, and 7. Multi-temporal images (winter and summer) and a progressive classification scheme were used to improve class separability. In the progressive clustering process, each superclass is first classified using the k-means clustering algorithm (Tou \& Gonzalez, 1974). The major categories are then masked individually per superclass and the progressive clustering process is performed on each category. After several clustering iterations of the masked data, classification labels are assigned to the spectral clusters. The final classification results are then modeled together to produce a final image classification.

Classification error estimates are generated using a geometric, stratified-random sampling technique in which 50 points are selected per class and verified using field data. An accuracy assessment performed on the 1998 image classification yielded an overall accuracy of $79 \%$. Due to the large homogeneous areas of sand pine on Eglin, sand pine was classified with $92 \%$ producer's accuracy. The longleaf pine classification had a producer's accuracy of $66 \%$, with the majority of the error resulting from the misclassification of longleaf with the scrub/shrub class.

A multiple-date change detection technique using a binary change mask is used to generate subsequent image classifications. The Normalized Difference Vegetation Index (NDVI) is generated for each year and then classified together using the k-means clustering algorithm. Four images are included in the classification: winter and summer NDVI from the latest classification and winter and summer images from the current classification year. From the resulting classification, areas of change are identified and masked out for classification. The same technique described above for the baseline classification is applied to these areas of change to generate current date classifications.

\subsection{Current model applications and future directions}

The GIS model provides Eglin natural-resource managers with a simple, consistent, and easily shared method to evaluate the condition of longleaf pine forests without resource-intensive fieldwork. The model is run annually with updated inputs derived from satellite imagery to identify areas that experienced a change in condition class and to assess the cumulative impact of management efforts (Figs. 3 and 4). Most notably, areas that show a decline in Tier condition (e.g., move from Tier 1 to Tier 2) are used as high-priority inputs in Eglin's spatially explicit burn prioritization model (Hiers et al., 2003a), which is used to prioritize fire management activities on the base. Thus, burn blocks with sandhills that decline in condition are treated with prescribed fire sooner than they would have been in the original burnblock rotation. In addition, when proposed actions require an Environmental Impact Statement under the National Environmental Policy Act (NEPA), the model results are used to determine if an action will impact Tier 1 habitat. The model results are also used in conjunction with FNAI data to inform Eglin's annual natural resources planning for timber, game, and recreation activities. Finally, vegetation abundance data collected from the permanent 1-ha monitoring plots are currently being examined with multivariate techniques including non-metric multidimensional scaling (NMS), clustering analysis, classification and regression trees (CART), and indicator species analysis to streamline monitoring efforts and to improve the accuracy of the condition model. For example, Euclidean and Mahalanobis distances to the centroid of reference sandhills plots in NMS ordination space are being used to assign tier condition classes to sandhills monitoring plots, which are in turn compared to the results of the GIS condition model. Fig. 5 summarizes the approach and 

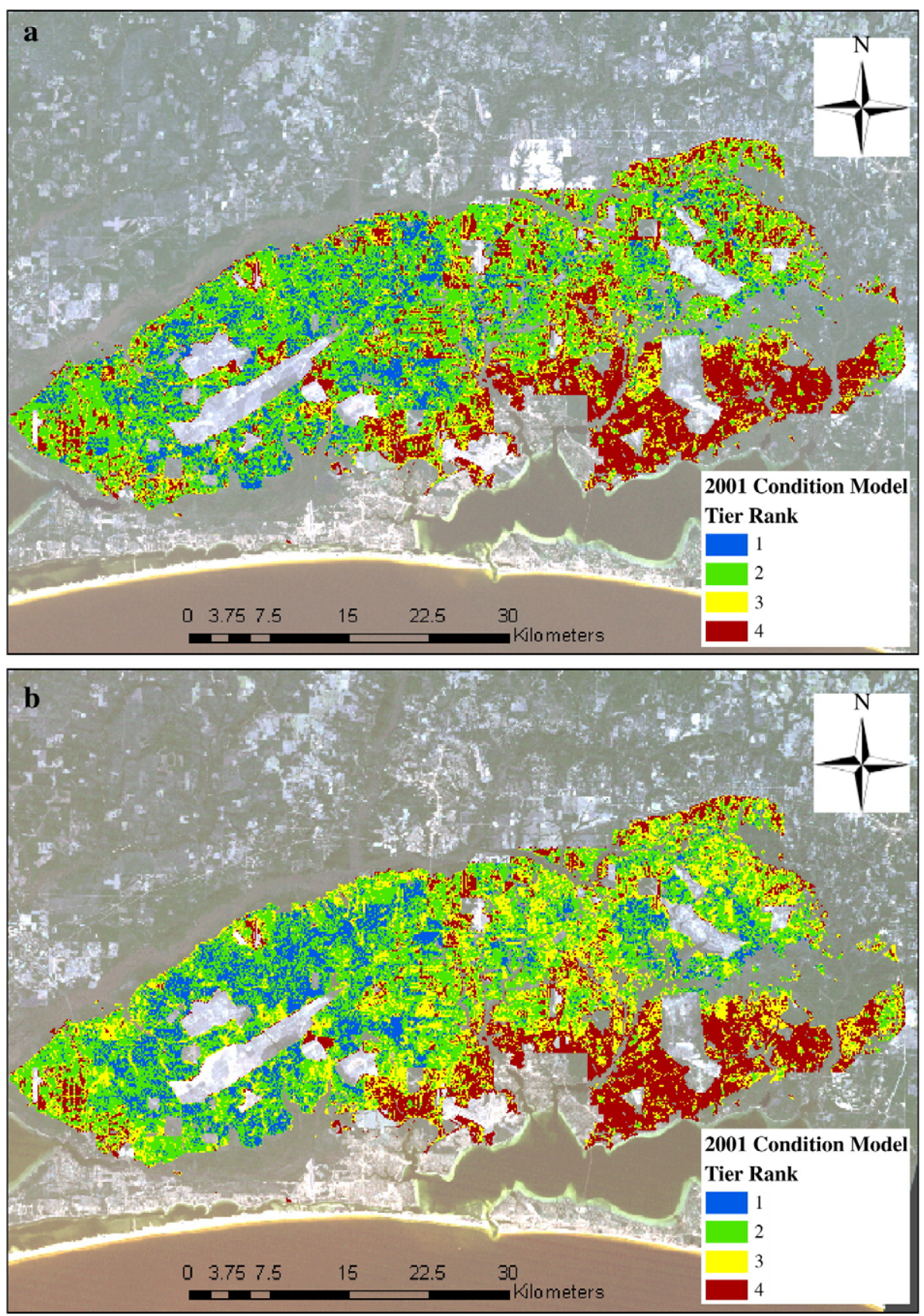

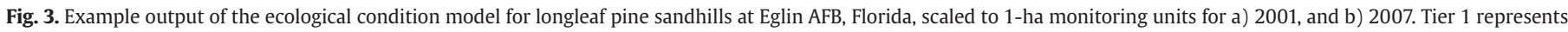
high-quality sandhills while Tier 4 reflects degraded sandhills.

applications of the ecological condition model and illustrates the role of remote sensing.

In the future, higher resolution imagery and new cognitive software programs to perform fuzzy classification of satellite imagery may be used to improve the derivation of model inputs. Although the GIS model was created and validated by experts, a ground validation of the model has not yet been conducted. Eglin natural resources staff and TNC are exploring the possibility of convening experts to perform an on-theground validation of the 2007 GIS model results. The results of such an assessment would be used to improve the model and provide an accuracy assessment of the model's performance. In addition, rates of change in the tier condition of the sandhills can be examined to determine an appropriate time interval at which to run the model. Finally, the potential to use newer, spatially explicit modeling approaches such as MAXENT (Phillips et al., 2006) to examine the condition of Eglin's sandhills using remotely sensed data is also being explored.

\section{Case study 3: Evaluating the effectiveness of forest conservation strategies}

Our third example illustrates how remote sensing is being applied to assess the effectiveness of forest conservation strategies used by The Nature Conservancy (TNC) in a study now underway. The strategies include direct acquisitions, acquisitions by third parties, conservation easements, and forest certification. What sets this study apart is how remote sensing is being used to assess forest cover changes observed across large areas with different forest types and management goals, while still providing high-quality, comparable data that allow characterization, quantification and interpretation of changes based on site-specific conservation objectives.

The timber industry has changed dramatically in the last decade as traditional integrated forest-product companies have divested of extensive acreage across the United States. (Wilent, 2004; Mendall 


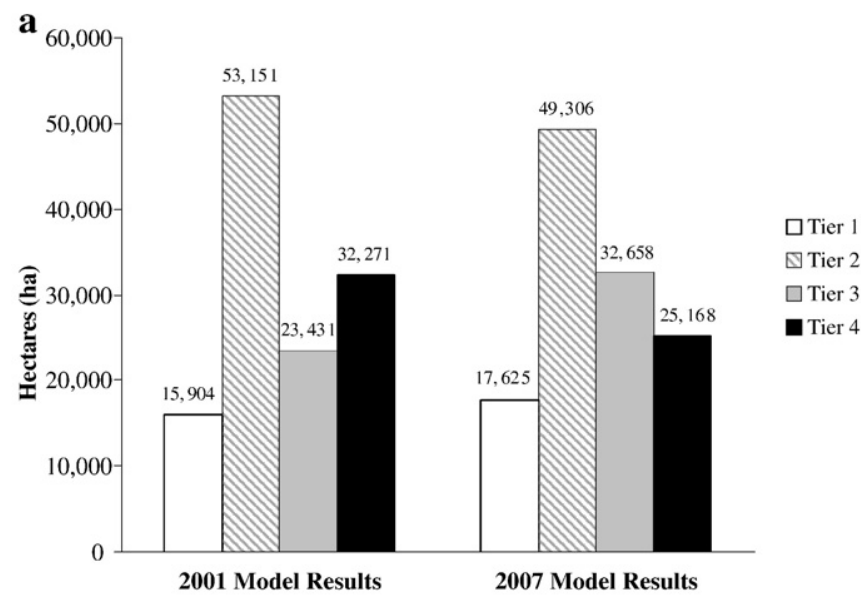

b

\begin{tabular}{ccccccc} 
& \multicolumn{5}{c}{ 2007 Model Results (ha) } \\
& & Tier 1 & Tier 2 & Tier 3 & Tier 4 & 2001 Totals \\
\cline { 2 - 7 } 2001 & Tier 1 & 9,863 & 5,793 & 223 & 25 & 15,904 \\
$\begin{array}{c}\text { Model } \\
\text { Results } \\
\text { (ha) }\end{array}$ & Tier 2 & 7,703 & 36,540 & 8,494 & 414 & 53,151 \\
& Tier 3 & 55 & 5,349 & 13,518 & 4,509 & 23,431 \\
\cline { 2 - 7 } & Tier 4 & 4 & 1,624 & 10,423 & 20,220 & 32,271 \\
\hline 2007 Totals & 17,625 & 49,306 & 32,658 & 25,168 & 124,757
\end{tabular}

Fig. 4. a) Change in longleaf pine condition tier by area (ha) from 2001 to 2007 at Eglin AFB as assessed by the ecological condition model. b) A matrix showing how the tier values of Eglin's 1-ha management units transitioned from 2001 to 2007. For example, 7703 ha moved from Tier 2 to Tier 1 over the time period. Shaded cells indicate 1 -ha management units that did not experience a change in condition from 2001 to 2007 (total of $80,141 \mathrm{ha}$ ).

et al., 2005; Clutter et al., 2006). These changes in forest-land ownership have provided conservation groups with unique opportunities to protect significant areas of forest. Collectively, the decisions on how much, to whom, and with what restrictions these forest lands are assigned are the "conservation strategies." These strategies include directly managing the timber on the property, selling the lands to private or public entities under the protection of conservation easements, facilitating sales to government agencies, and ensuring that forests are covered by thirdparty certification programs. The effectiveness of these strategies in helping to achieve forest conservation goals is largely untested. The study uses a retrospective analysis of forest conditions across various patterns of ownership and legal protections to assess the effectiveness of the different strategies (Table 4).

\subsection{Remote-sensing approach}

Because surveying forest cover change/health on the ground is demanding in time, personnel, and money when conducted across large areas (as in this study) and access to private lands is often not allowed, an alternative approach is needed. Forest cover changes can be assessed across large areas through remote sensing (AguilarAmuchastegui \& Henebry, 2007; Ashton \& Hall, 1992; Wulder, 1998; Jin \& Sader, 2005; Lu et al., 2004; Shiba \& Itaya, 2006). The approach used must be sensitive enough to allow detection of changes at adequate spatial scales, in a timely manner, and with enough flexibility so it can be used to assess different management objectives in different types of ecosystems. It must be useable by managers and technicians with varied backgrounds and expertise. This study's objective is to detect and quantify changes in forest cover, interpret them based on specific management objectives established for each forest stand, and then measure strategy effectiveness with a minimal amount of data processing. Those stands requiring further assessment or verification then can be targeted for additional data analysis and/or ground surveys.
A wide array of sensors such as Landsat TM, ETM+, IRS and SPOT and, more recently, ALOS, EO-1 ALI, ASTER have proven to be the most versatile for forest-stand parameter estimation, as their spatial resolutions $(15-30 \mathrm{~m})$ are consistent with the average quadrant sizes used when surveying structural parameters in the field (Aguilar-Amuchastegui \& Henebry, 2007; Lu et al., 2004; Rosenqvist et al., 2007). We are using Landsat based on its 30+ years of accumulated data (now being released), extensive research on its use for forest cover change monitoring, and the development of straightforward and easily implemented techniques for its use for change and/or disturbance detection, such as Kauth-Thomas's "Tasseled Cap Transformation" (TCT) differences (Collins \& Woodcock, 1996).

In this study, changes in the brightness $(B)$, greenness $(G)$, and wetness $(W)$ indices resulting from the Tasseled Cap transformation (TCT index differencing) of images acquired between survey periods (see Jin \& Sader, 2005) are being used to detect and classify changes related to forest management practices. These include stand growth and loss, planting, fire frequency and area, thinning, and harvest (Coops et al., 2006; Dymond et al., 2002; Healey et al., 2005, 2006; Jin \& Sader, 2005; Levien et al., 1999; Sivanpillai et al., 2006; Skakun et al., 2003; Wulder et al., 2004).

TCT index differencing is a practical approach, as it does not require complicated image-processing steps such as top-of-the-canopy atmospheric correction. Differences of indices derived from top-of-atmosphere reflectance (Markham \& Baker, 1986; Peddle et al., 2003; Wulder et al., 2004) have been shown to be robust against atmospheric anomalies (Song et al., 2001). Additionally, index differencing incorporates forest dynamics as part of the analysis rather than considering it as a source of potential error or bias (see Aguilar-Amuchastegui \& Henebry, 2006, 2007).

Changes observed in the three indices $(B, G, W)$ across time are represented by a three-band change image $(\triangle B G W)$, and then classified into change classes (see Fig. 6; Healey et al., 2005; Levien et al., 1999). As forests in general are dynamic (Aguilar-Amuchastegui \& Henebry, 2007), stands will exhibit pixels belonging to specific change classes. Those classes are then linked to similar changes observed in reference areas such as a known burned stand or a stand where we know thinning has occurred. Change classes occurring within each stand, their type, the area covered, and dimension are then interpreted and translated into stand conservation scores based on specific management objectives and goals (e.g. forest cover area loss/gain, expected number acres burned, thinned, harvested, untouched). By translating the specific changes detected and quantified by remote sensing into management-based conservation scores, we put changes observed across the study area into a common scale, allowing direct comparison of the results. Conservation scores are then grouped according to each conservation strategy in order to assess its effectiveness (Fig. 6).

\section{Summary and conclusions}

These case studies illustrate how remote sensing can be used to establish spatial priorities, assess the condition of ecological systems, and evaluate the effectiveness of management practices or strategies. In the Connecticut River watershed, for example, remote sensing allowed us to verify current flood regimes at specific sites and assess them against the flood regime of the entire stream network. Additionally, it proved useful in separating floodplain forest communities from other riparian community types. At Eglin AFB, remote sensing has provided information to assess the effectiveness of management strategies to restore fire to the longleaf pine sandhills ecosystem, control invasive species, and prioritize annual prescribed burns at multiple scales. In eastern US forests, remote sensing is being used to perform a retrospective study that could not otherwise be 
Time 1

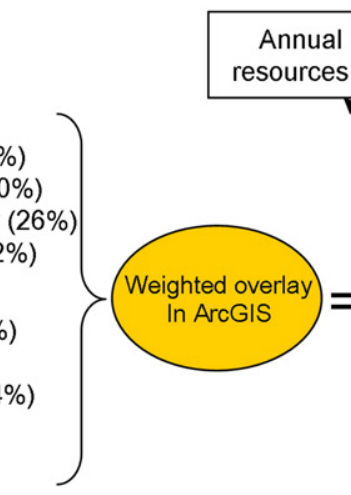

- Canopy Density $(10 \%)$

- Deciduous Cover $(10 \%)$

- Longleaf pine Cover (26\%)

- Sand pine Cover (12\%)

- Fire Sub-model (18\%)

GIS Data Layers

- Patch Size $(6 \%)$

- RCW Sub-model (14\%)

- Road density (4\%)

Time 2
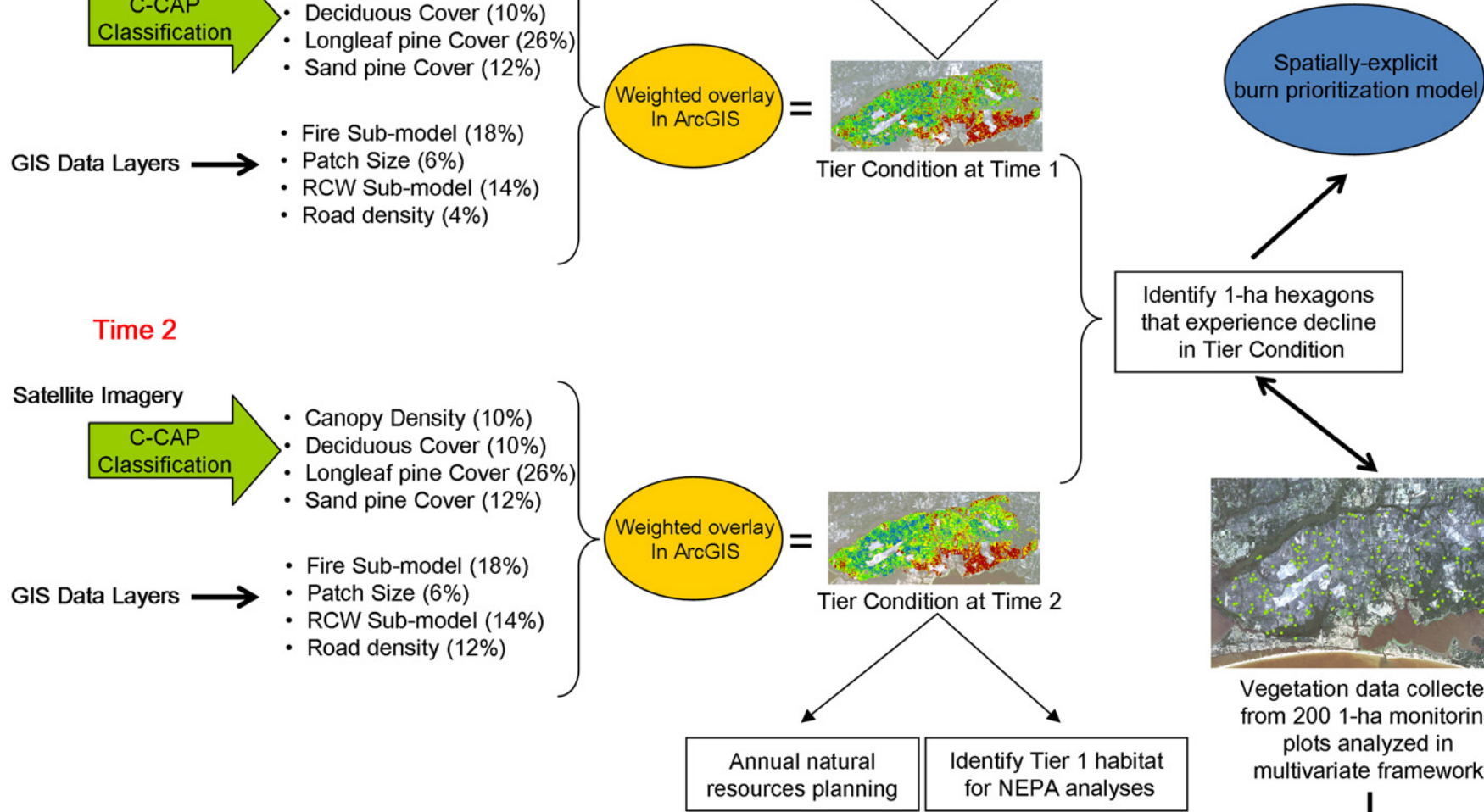

Identify 1-ha hexagons

that experience decline in Tier Condition
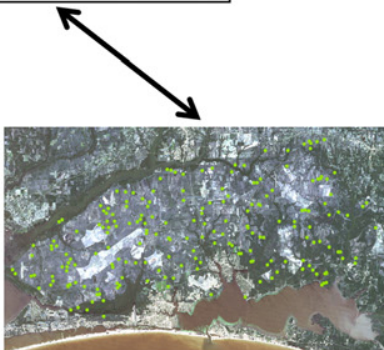

Vegetation data collected from 200 1-ha monitoring plots analyzed in multivariate framework

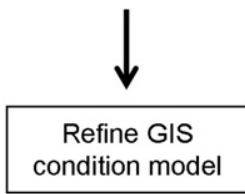

Fig. 5. Flow chart summarizing the spatial modeling approach used to assess the ecological condition of longleaf pine sandhills across Eglin AFB.

done, to cover a spatial extent and a diversity of forest types that would be prohibitively expensive if conducted on the ground, and to enable us to evaluate condition and changes in properties where direct access would be difficult or impossible to obtain.

These case studies also illustrate several issues that are essential to consider in the application of remote sensing to support conservation efforts.

\section{Table 4}

Response variables to be measured in the analysis of forest-conservation strategies in eastern US.

\begin{tabular}{|c|c|c|c|}
\hline $\begin{array}{l}\text { Ecological attributes } \\
\text { (remote sensing) }\end{array}$ & $\begin{array}{l}\text { Ecological attributes } \\
\text { (ground sampling) }\end{array}$ & $\begin{array}{l}\text { Threat attributes } \\
\text { (remote sensing) }\end{array}$ & $\begin{array}{l}\text { Legal/conservation } \\
\text { Status (background } \\
\text { information) }\end{array}$ \\
\hline Forest cover & $\begin{array}{l}\text { Coarse woody } \\
\text { debris }\end{array}$ & Development & Date of sale \\
\hline Forest structure & $\begin{array}{l}\text { Herbaceous } \\
\text { diversity }\end{array}$ & Land conversion & Ownership status \\
\hline Forest composition & Avian diversity & Management & Protection status \\
\hline Forest fragmentation & Carnivore diversity & impacts & Legal restrictions \\
\hline Forest size/natural & Water quality & $\begin{array}{l}\text { Recreation } \\
\text { impacts }\end{array}$ & Use restrictions \\
\hline disturbance ratio & Hydrologic regime & Roads & $\begin{array}{l}\text { Forest certification } \\
\text { status }\end{array}$ \\
\hline Intact riparian buffer & Atmospheric & $\begin{array}{l}\text { Pests and } \\
\text { pathogens }\end{array}$ & \\
\hline Fire management & deposition & Fire management & \\
\hline Topography & Invasives & Timber harvest & \\
\hline Slope & Deer herbivory & & \\
\hline Flooding regime & Fire management & & \\
\hline
\end{tabular}

\subsection{Spatial and temporal resolution}

First, it is critical to identify the appropriate spatial and temporal resolution necessary to answer the conservation question or questions at hand. Conservation planning occurs over a range of scales, from global to local. At global and even regional scales, the need for broad and consistent coverage of data layers is more important than the spatial resolution of the data. At the local scale where conservation planning is actually implemented, however, high-resolution information is often required to consider how threats, opportunities, resources, or compatible land uses are arrayed across the landscape. Similarly, assessing how these places change as a result of land use, disturbances, or management actions may require high temporal resolution. For both spatial and temporal dimensions, however, the higher the resolution of the data the greater the "noise"-information that is tangential to the variables of interest and that may cloud or obscure patterns in those variables. Care must be taken to separate signal from noise.

\subsection{Linking remote sensing to ground sampling}

In all of these situations, remote sensing is being linked with onthe-ground monitoring and data collection. This combined approach increases the cost-effectiveness of monitoring by directing ground surveys where they can contribute the most. Moreover, by assessing variables that are not easily amenable to remote sensing, such as herbaceous diversity, occurrence of rare species, avian diversity, invasive species, carnivore diversity, or woody debris, on-the-ground 


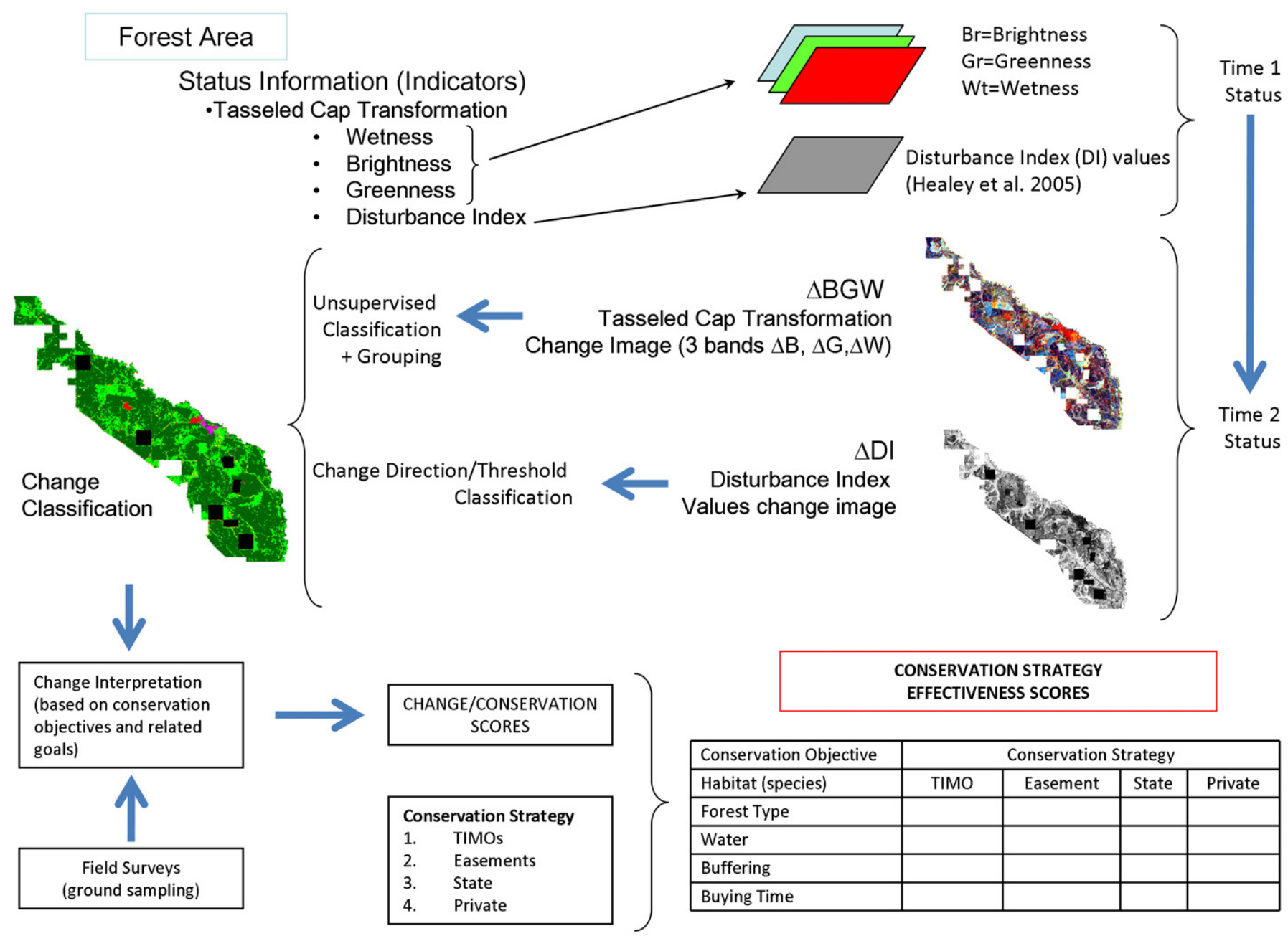

Fig. 6. Flow chart of the remote-sensing approach designed for assessing forest-conservation strategy effectiveness in the eastern United States.

surveys can provide the information necessary to attach ecological meaning to the patterns revealed by remote sensing. The work at Eglin AFB is an excellent example of maximizing the accuracy of remote sensing while streamlining the ground sampling for validation and the addition of variables that cannot be assessed in any other way. This should enable management based on an understanding of ecological processes as well as patterns. Remote sensing is a valuable tool, but it is not a panacea for the challenges of conducting ecological monitoring and implementing sound management.

\subsection{Objective-driven remote sensing}

The technological foundation, resolution, and capacity of remote sensing are rapidly expanding. Yet as remote sensing produces more and better data of more varied sorts, the need for sound ecological interpretation becomes increasingly important. Remote sensing can provide a deluge of data, and one could argue (as many have done) that one can never have too much data. For this information to be useful in conservation and management, however, it must be interpreted. If remote sensing detects a certain amount of landscape change, what does this mean for conservation? Is a spatial pattern that is revealed at a $1-\mathrm{m}^{2}$ resolution really relevant to the conservation questions that are being asked? At what point does the availability of ever more sophisticated remote-sensing tools become technological overkill?

Interpreting remote-sensing data requires an understanding not only of ecology but of the particulars of how information is obtained and processed by remote sensing. As the technology advances, it grows in complexity and may quickly exceed the comfort level of most ecologists. And ecology is also growing more complex, exceeding the comfort level of most people trained in remote sensing. Few individuals are likely to have deep expertise in both. The gap between people versed in data generation and those skilled in data interpretation is likely to widen. Broader training by itself will not bridge this gap. Rather, collaborations between scientists who understand the details and latest advances in remote sensing and those who deal with the scientific underpinnings of conservation will be essential. Workshops targeted at particular problems or places may be an effective way to share ideas and foster these collaborations.

\subsection{Resources for remote sensing}

Cost is important. Conservation organizations are always limited in funds, since the needs for conservation action will always outstrip the availability of funding. This means that organizations must assess their funding priorities. At some point, spending more to obtain higher-resolution imagery at finer temporal resolution, and to analyze and interpret the greater quantity of information such imagery provides, will exceed the level of resolution needed to make sound management decisions. There are diminishing returns on the investment. The temptation to use increasingly sophisticated and detailed remote-sensing tools and information because they are available must be tempered by the costs and the returns.

Answering this question requires that we ask, "How good is good enough?" How much information is needed, at what level of resolution and what expense? This decision should be guided by the 
objectives, the questions being asked, and the scale of the resulting conservation or management action. Using $\mathrm{m}^{2}$-resolution information to assess habitat condition and availability for a wide-ranging vertebrate may be overkill, but it may be essential for a plant species with restricted habitat requirements or to detect emerging threats. Determining how best to use remote sensing in conservation requires that the specific conservation objectives be clearly defined and then matched against the technological options available.

Remote sensing has proven its value and holds even greater promise for conservation in the future. Although new technology will be continually incorporated, it is equally important to apply remote sensing in ways that will most benefit the conservation of biodiversity.

\section{Acknowledgments}

We thank Charles Ferree, Arlene Olivero, and Feng Zhoa for assistance in the analysis (Connecticut River study), Jackson Guard and Kevin Hiers for their leadership and collaboration in longleaf pine management at Eglin AFB, and several anonymous reviewers for penetrating comments on an initial draft of this paper. Thanks also to John Gross, Josef Cihlar, and Scott Goetz for inviting us to contribute to this special issue.

\section{References}

Aguilar-Amuchastegui, N., \& Henebry, G. M. (2007). Indicators for tropical forests: Forest structure, dynamic change, logging intensity, and dung beetles. Forest Ecology and Management (http://dx.doi.org/10.1016/j.foreco.2007.07.004).

Anderson, M. G., Olivero, A., Feree, C., Morse, D., \& Khanna, S. (2006). Conservation status of the Northeastern U.S. and Maritime Canada. Boston, MA: The Nature Conservancy, Eastern Resource Office.

Ashton, P. S., \& Hall, P. (1992). Comparisons of structure among mixed dipterocarp forests of north-western Borneo. Journal of Ecology, 80, 459-481.

Clutter, M., Newman, D., Wear, D., Mendell, B., \& Greis, J. (2006). The changing landscape of timberland ownership in the south. Final Report, USDA Forest Service Working Paper. Asheville, NC: Southern Research Station.

Collins, J. B., \& Woodcock, C. E. (1996). Explicit consideration of multiple landscape scales while selecting spatial resolutions, Spatial accuracy assessment in natural resources and environmental sciences: Second International Symposium, Fort Collins, CO (pp. 121-128).

Coops, N. C., Wulder, M. A., \& White, J. C. (2006). Integrating remotely sensed and ancillary data sources to characterize a mountain pine beetle infestation. Remote Sensing of Environment, 105, 83-97.

Dobson, J. E., Bright, E. A., Ferguson, R. L., Field, D. W., Wood, L. L., Haddad, K. D., et al. (1995). NOAA Coastal Change Analysis Program (C-CAP): Guidance for regional implementation. NOAA Technical Report NMFS 123, NTIS, Springfield VA.

Dymond, C. C., Mladenoff, D. J., \& Radeloff, C. (2002). Phenological differences in Tasseled Cap indices improve deciduous forest classification. Remote Sensing of Environment, 80, 460-472.

Dynesius, M., \& Nilsson, C. (1994). Fragmentation and flow regulation of river systems in the northern third of the world. Science, 266, 753-761.

Fels, J., \& Matson, K. C. (1997). A cognitively-based approach for hydrogeomorphic land classification using digital terrain models. www.ncgia.ucsb.edu/conf/SANTA_ FE_CD-ROM/sf_papers/fels_john/fels_and_matson.html

Florida Natural Areas Inventory (1999). Tracking list of rare, threatened, and endangered plants and animals and natural communities of Florida. Tallahassee, Florida: Florida Natural Areas Inventory.

Groves, C. R. (2003). Drafting a conservation blueprint. Washington DC: Island Press.

Healey, S. P., Cohen, W. B., Zhiqiang, Y., \& Krankina, O. N. (2005). Comparison of tasseled cap-based Landsat data structures for use in forest disturbance detection. Remote Sensing of Environment, 97, 301-310.

Healey, S. P., Zhiqiang, Y., Cohen, W. B., \& Pierce, J. D. (2006). Application of two regression-based methods to estimate the effects of harvest on forest structure using Landsat data. Remote Sensing of Environment, 101, 115-116.

Henry, C. P., \& Amoros, C. (1995). Restoration ecology of riverine wetlands: I. A scientific base. Environmental Management, 19, 891-902.

Hiers, J. K., Laine, S. C., Bachant, J. J., Furman, J. H., Greene, W. W., Jr., \& Compton, V. (2003). Simple spatial modeling tool for prioritizing prescribed burning activities at the landscape scale. Conservation Biology, 17, 1571-1578.

Hiers, J. K., Mathers, J., Stevens, A., Lee, E., Laine, S., Harod, J., et al. (2003, September). Progress report of Eglin AFB ecological monitoring program 2000-2003. Eglin Air Force Base Natural Resource Branch at Jackson Guard.

Hoekstra, J. M., Boucher, T. M., Ricketts, T. H., \& Roberts, C. (2005). Confronting a biome crisis: Global disparities of habitat loss and protection. Ecology Letters, 8, 23-29.

Janzen, D. H. (1983). No park is an island: increase in interference from outside as park size decreases. Oikos, 41, 402-410.

Jin, S. M., \& Sader, S. A. (2005). Comparison of time series tasseled cap wetness and the normalized difference moisture index in detecting forest disturbances. Remote Sensing of Environment, 94, 364-372.
Kareiva, P., \& Marvier, M. (2003). Conserving biodiversity coldspots. American Scientist, 91, 344-351.

Kearsley, J. B. (1999). Inventory and vegetation classification of floodplain forest communities in Massachusetts. Rhodora, 101, 105-136.

Kindell, C. E., Herring, B. J., Nordman, C., Jensen, J., Schotz, A. R., \& Chafin, L. G. (1997) Natural community survey of Eglin Air Force Base, 1993-1996: Final report. Tallahassee, FL: Florida Natural Areas Inventory.

Levien, L., Roffers, P., Maurizi, B., Suero, J., Fischer, C., \& Huang, X. (1999). A machinelearning approach to change detection using multi-scale imagery. Proceedings of ASPRS Annual Conference (1,22, Portland, OR). Bethesda, MD: American Society for Photogrammetry and Remote Sensing (ASPRS).

Loveland, T. R., Sohl, T. L., Stehman, S. V., Gallant, A. L., Sayler, K. L., \& Napton, D. E. (2002). A strategy for estimating the rates of recent United States land-cover changes. Photogrammetric Engineering and Remote Sensing, 68, 1091-1099.

Lu, D. S., Mausel, P., Brondizio, E., \& Moran, E. (2004). Relationships between forest stand parameters and Landsat TM spectral responses in the Brazilian Amazon basin. Forest Ecology and Management, 198, 149-167.

Markham, B. L., \& Baker, J. L. (1986). Landsat MSS and TM post-calibration dynamic ranges, exoatmospheric reflectances and at-satellite temperatures. EOSAT Landsat Technical Notes, 1, 3-7 (Lanham, MD).

Mendall, B., Newman, D., Wear, D., \& Greis, J. (2005). Under new management: A case study of southern timberland ownership changes. Final Report-USDA Forest Service Working Paper. Asheville NC: Southern Research Station.

Myers, N., Mittermeier, R., Mittermeier, C. G., Da Fonseca, G. A. B., \& Kent, J. (2000). Biodiversity hotspots for conservation priorities. Nature, 403, 853-858.

Nichols, W. F., Sperduto, D., Bechtel, D. A., \& Crowley, K. F. (2000). Floodplain forest natural communities along minor rivers and large streams in New Hampshire. Concord, NH: New Hampshire Natural Heritage Inventory.

Olivero, A. P. (2003). Development of a GIS based freshwater classification and conservation prioritization in Lower New England. Masters Thesis. Department of Biology. University of Massachsuetts-Boston. 203p.

Olson, D. M., \& Dinerstein, E. (1998). The Global 200: A representative approach to conserving the Earth's most biologically valuable ecoregions. Conservation Biology, $12,502-515$.

Peddle, D. R., Franklin, S. E., Johnson, R. L., Lavigne, M. B., \& Wulder, M. A. (2003) Structural change detection in a disturbed conifer forest using a geometric optical reflectance model in multiple-forward mode. IEEE Transactions on Geoscience and Remote Sensing, 41, 163-166.

Phillips, S. J., Anderson, R. P., \& Schapire, R. (2006). Maximum entropy modeling of species geographic distributions. Ecological Modelling, 190, 231-259.

Rosenqvist, A., Shimada, M., Ito, N., \& Watanabe, N. (2007). ALOS PALSAR: A Pathfinder mission for global-scale monitoring of the environment. IEEE Transactions on Geoscience and Remote Sensing, 45, 3307-3316.

Scott, J. M., Davis, F. W., McGhie, G., \& Groves, C. (2001). Nature reserves: Do they capture the full range of America's biological diversity? Ecological Applications, 11 999-1007.

Shiba, M., \& Itaya, A. (2006). IUFRO. Precision Forestry Symposium Proceedings (pp. 351-360). South Africa: Stellenbosch University.

Sivanpillai, R., Smith, C. T., Srinivasan, R., Messina, M. G., \& Wu, X. B. (2006). Estimation of managed loblolly pine stand age and density with Landsat ETM+ data. Forest Ecology and Management, 223, 247-252.

Skakun, R., Wulder, M., \& Franklin, S. (2003). Sensitivity of the thematic mapper enhanced wetness difference index (EWDI) to detect mountain pine beetle redattack damage. Remote Sensing of Environment, 86, 433-443.

Song, C., Woodcock, C. E., Seto, K. C., Lenney, M. P., \& Macomber, S. A. (2001). Classification and change detection using Landsat TM data: When and how to correct atmospheric effects? Remote Sensing of Environment, 75, 230-244.

Sorenson, E., Lapin, M., Engstrom, B., \& Popp, R. (1998). Floodplain forests of Vermont. Some sites of ecological significance. Unpublished report submitted to the U.S. Environmental Protection Agency, Vermont Nongame and Natural Heritage Program, Waterbury, VT.

Steinberg, D., \& Colla, P. (1997). CART-Classification and regression trees. San Diego, CA: Salford Systems.

Strager, J.M., Yuill, C.B., \& Wood, P.B. (2000). Landscape-based riparian habitat modeling for amphibians and reptiles using Arc/Info Grid and ArcView GIS, West Virginia GAP Project, unpublished paper.

Sutter, R. D., Bachant, J. J., Gordon, D. R., \& Litt, A. R. (2001). An assessment of the desired future conditions for focal conservation targets on Eglin Air Force Base. Report to Natural Resources Division, Eglin Air Force Base, Niceville, Florida. Gainesville, Florida: The Nature Conservancy.

Thompson, E. H., \& Sorenson, E. R. (2000). Wetland, woodland, wildland. Hanover, NH: University Press of New England.

Tou, J., \& Gonzalez, R. C. (1974). Pattern recognition principles. Addison-Wesley.

U.S. Department of the Air Force (1998). Integrated natural resources transitional plan, Eglin Air Force Base. Niceville, Florida: Eglin Air Force Base, Eglin Natural Resources Division.

U.S. Fish and Wildlife Service (2003). Recovery plan for the red-cockaded woodpecker (Picoides borealis): Second revision. Atlanta, Georgia: U.S. Fish and Wildlife Service.

Wang, Y. (2004). Using Landsat 7 TM data acquired days after a flood event to delineate the maximum flood extent in a coastal floodplain. International Journal of Remote Sensing, 25, 959-974.

Wang, Y., Colby, J. D., \& Mulcahy, K. A. (2002). An efficient method for mapping flood extent in a coastal floodplain using Landsat TM and DEM data. International Journal of Remote Sensing, 23, 3681-3696.

Wiens, J. A. (2007). Does conservation need landscape ecology? A perspective from both sides of the divide. In D. B. Lindenmayer \& R. J. Hobbs (Eds.), Managing 
and designing landscapes for conservationMoving from Perspectives to Principles (pp. 479-493). Oxford UK: Blackwell Publishing.

Wiens, J. A., Anderson, M. G., \& Boucher, T. (in press). Land cover and conservation: From protected areas to landscapes. Annals of the Association of American Geographers.

Wilent, S. (2004, December). Investors increase timberland holdings. The Forestry Source, $9,1-4$.
Wulder, M. A. (1998). Optical remote-sensing techniques for the assessment of forest inventory and biophysical parameters. Progress in Physical Geography, 22, 449-476.

Wulder, M., Skakun, R., Kurz, W., \& White, J. (2004). Estimating time since forest disturbance using segmented Landsat ETM+ imagery. Remote Sensing of Environment, 3, 179-187. 